\title{
Fishing Crafts and Gears in Buug, Dumanquillas Bay, Philippines
}

\author{
Bryan L. Bitantos ${ }^{1}$, Lovena Grace Amor T. Dela Cruz ${ }^{2}$, Jay Pril M. Natuil ${ }^{3} \&$ Wellmor John R. Sabado ${ }^{4}$ \\ ${ }^{1}$ Mindanao State University - Buug Campus, Zamboanga Sibugay Province, Philippines \\ Correspondence: Bryan L. Bitantos, Mindanao State University - Buug Campus, Datu Panas, Buug, Zamboanga \\ Sibugay Province, Philippines. Tel: 63-91-7721-2060 E-mail: bitantosbryan@gmail.com
}

Received: February 6, 2021

Accepted: March 6, 2021

Online Published: September 27, 2021

doi:10.20849/jess.v4i1.927

URL: https://doi.org/10.20849/jess.v4i1.927

\begin{abstract}
Dumanquillas Bay is a body of saltwater and the major source of food located in the Southern Mindanao. It has been observed that marine resources and fish catch in the area are declining. This study assumed that fishing practices affect the decline of marine and fish catch in the bay. A study on the documentation of fishing practices in the area is reported here. Key informant interview (KII), focus group discussion, direct observation and document archival were used. Twenty-three (23) fishing practices were observed in the area. Based on R.A. 10654 or the Philippine Fisheries Code, five (5) fishing practices were identified in the bay which are illegal. These are "pahulbot sa lalum", "pahulbot sa mabaw", "panubli", "panguryente" and "troll" that destroys sea grasses, coral reefs and the sea beds. The illegal fishing practices identified poses a threat to the marine resources. It implies weak implementation of fishing policies among the LGU's and other concerned government institutions and NGA's. Capacity building, CEPA campaign and committed implementation of the Philippine Fisheries Code (R.A. 10654) should be implemented by the PAMB and stakeholders in the community to manage the remaining coastal marine resources thereby uplifting the socio-economic status of the coastal community and achieve sustainability.
\end{abstract}

Keywords: dumanquillas bay, fishing practices, fishing gears, fishing crafts, marine resources

\section{Introduction}

The Republic of the Philippines situated in the Pacific Ocean near the equator consists of around 7,640 islands - about 2,000 of which are inhabited - that formed an archipelago (National Geographic, 2021). Majority of Philippine cities and municipalities are coastal communities and are populated by about 60 percent of the total population (Pomeroy et al., 2006; White \& Cruz-Trinidad, 1998). Coastal communities' primary sources of livelihood include fishing, seaweed farming, mangrove lumber, harvesting of seashells, and aquaculture businesses (Coastal Communities - GOV.PH, n.d.). Coastal areas typically have both highly valuable and productive ecosystem and extraordinarily high levels of human economic activities. In many coastal areas, this has led to over-exploitation of coastal resources and severe degradation of the environment. Fishermen use a wide range of gear to onshore their catch. Every type has its own effects on the ocean. By selecting the right gear for the right job, the fishing industry can help minimize its impact on the environment (Flewwelling et. al., 2003; Food and Agriculture Organization [FAO], 2005; Pauly, D., 1998).

Dumanquillas Bay is a body of seawater located in the southwestern part of Zamboanga Peninsula. It has a total area of 29,698 hectares covering six (6) municipalities in Zamboanga del Sur and Zamboanga Sibugay. This bay is the major source of marine products in Zamboanga Peninsula (Dumanquillas Bay Management Plan, 2021). The fisherfolks in the bay uses different fishing gears and crafts to catch fishes and other marine resources. These fishing practices may pose threat to the health of the environment. There is a need to assess the fishing gears and crafts being practiced in the area to eliminate the illegal fishing practice which destroys the marine ecosystem and promote the legal ones for the sustainability of the marine resources and ecosystem thereby uplifting the socio-economic status of the fisherfolks. This research work identified the fishing gears and crafts employed and practiced by the fisherfolks in Buug, Dumanquillas Bay, Philippines.

\section{Method}

\subsection{Description of the Study Site}

Dumanquillas Bay is a body of seawater located in the southwestern part of Zamboanga Peninsula. It has a total area of 29,698 hectares covering six (6) municipalities four (4) of it is located in Zamboanga del Sur and the two 
(2) is located in Zamboanga Sibugay. Municipalites located in Zamboanga del Sur includes the municipalities of Kumalarang, Lapuyan, Margos sa Tubig and Vincenzo Sagun. Municipalities located in Zamboanga Sibugay includes the municipalities of Buug and Malangas. The bay covered forty-one (41) barangays from the six (6) municipalities.

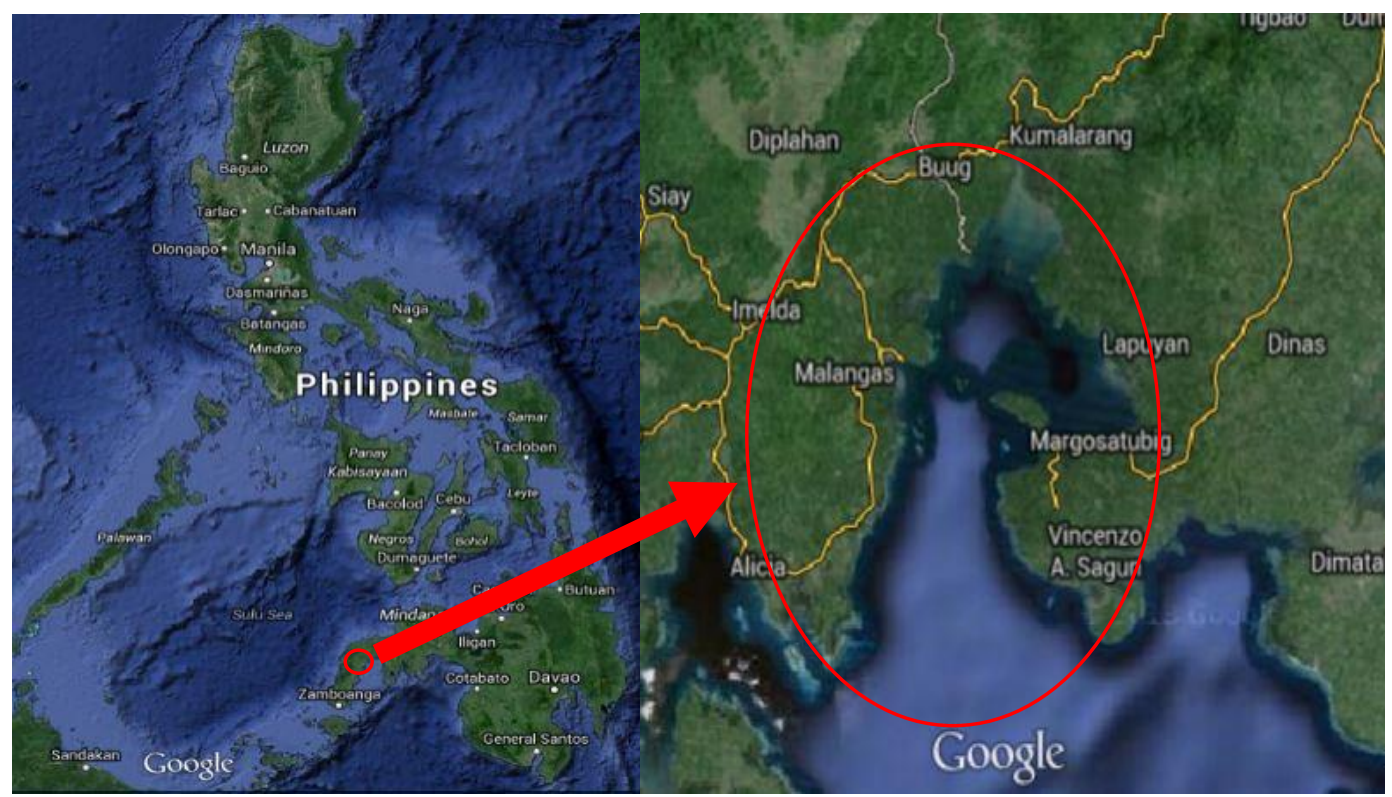

Figure 1. Location map of the study (Modified from Google Earth maps)

\subsection{Sampling Scheme}

The research activity was coordinated with the local residents of Pamintayan, Buug, Zamboanga Sibugay. The data gathering was done on November- December 2015. Barangay Pamintayan of Buug was selected as the sampling site because the majority of fishers in Buug lives in the area. The fishing gears of the fishers in Pamintayan are also located in other municipalites of Dumanquillas Bay. They have great knowledge on fishing and fishing practices. Key informant interview among the fisherfolks of Pamintayn was conducted to determine the different crafts and gears in the bay.

\section{Results and Discussion}

\subsection{Fishing Crafts and Gears}

\subsubsection{Kabyawan}

The fishing practice used a "payaw" which is a bundle of coconut leaves 50 pieces bundled together by a binder in a bamboo pole and strategically put up in the sea. It is like a pole submerged in the sea with coconut leaves from the base to the top of the bamboo pole. The bamboo pole is tied up to a rope called binder and a large stone is also being tied up that will serve as the base of the structure. The fishes will thrive in the payaw and it serve as their shelter. Eventually they will lay their eggs in the leaves of the coconut. After the payaw has been established, it will take about four (4) days to harvest fish in the structure. About a number of fourteen (14) people will do the harvesting and two (2) of them will dive beneath the payaw using a compressor to do the maneuvering of the fish net to catch the fish. The harvesters used one (1) sampan (big motorboat), two (2) dulong langkipan (small motor boat), and one small motor boat intended for service. The income is divided into two (2) halves. The first half is for the owner of the payaw and the other half is for the workers. The two (2) divers have greater share among the other workers. Usually, the income will range from Php 20,000.00 and above to be divided by the owner and the workers. Harvesting in payaw will take half day. 


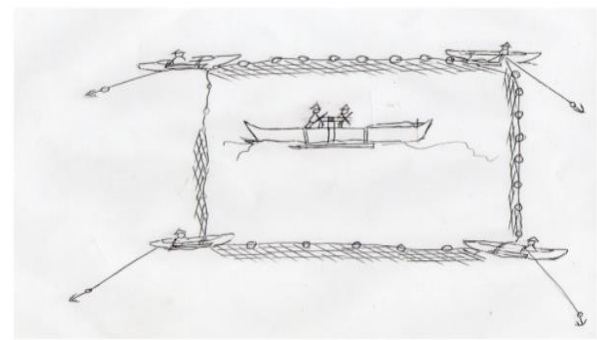

Figure 2. Kabyawan

\subsubsection{Bunsod}

"Bunsod" is a Visayan term in Pamintayan of fish corral or "baklad" in Tagalog. It is a kind of traditional fishing method where fish are being trapped. Bunsod in Pamintayan uses 350 bamboo poles, 10 feet each long or more depending on the depth of the sea. Bamboo species used in "bunsod" are "balidyawa" and "buntong" for its strength and durability. 1 piece of a 10 feet "balidyawa" is worth Php 40.00 while 1 piece of a 10 feet "buntong" is Php 150.00. The "bunsod" is constructed in a V-shaped. The opening of the V is the mouth which is a passage for the fish to enter on this huge fish structure. The back of the structure is something like a waiting area where fish are initially trap. On its side known as "bulsa" or pocket is the final destination of the fishes where they are totally trap. The bamboo poles are being fenced with net. Bunsod are constructed in area slightly facing seawater current. An approximate cost in constructing "bunsod" is Php 40,000.00. It can be finished by 3-4 days. On the day after the "bunsod" is constructed, it directly trapped fish. The fisherman harvests the fishes caught in "bunsod", early morning around 5:00 am. Bunsod fishing according to the fisherman, is a luck fishing. There are days when they can generate a gross income of Php 50.00 while sometimes they generate a gross income of Php10,000.00 plus in a day.

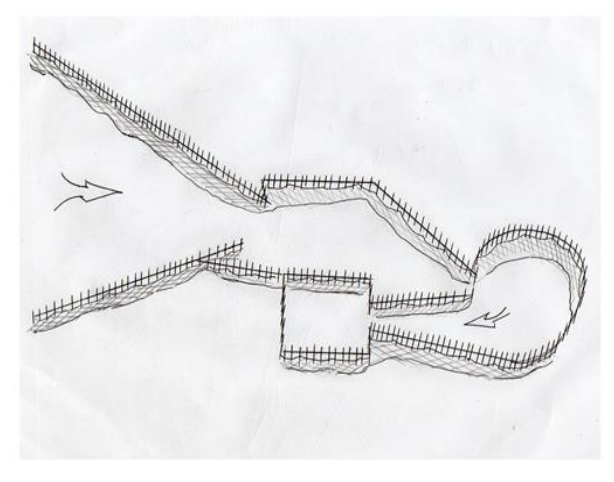

Figure 3. Bunsod

\subsubsection{Nyulok}

This fish structure is square in shape with posts in each edge. Usually nyulok posts are made up of bamboo poles or coconut timber. This fishing method employs a net which is like an inverted mosquito net put down under the sea. Nyulok fishing operates on nighttime, where a "lampara" is used to attract fish. It does not operate on daytime. When the fish will gather around on the light from the lampara, the fisherman usually two in number will bring the net above through the aid of a pulley. During full moon, nyulok fishing does not have a good fish harvest. An approximate amount of Php 120,000.00 is the cost in constructing 1 nyulok. Most nyulok does have a small bahay-kubo in the structure itself. This serve as resting or sleeping place by the fishermen while waiting for the fishes to gather. Nyulok in Pamintayan measures 13x14 feet. 


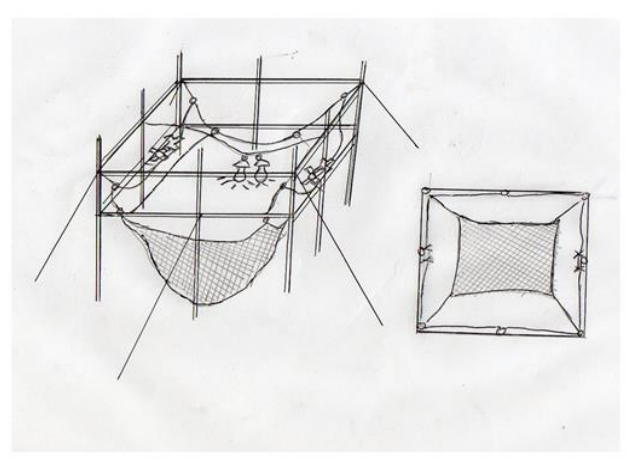

Figure 4. Nyulok

\subsubsection{Pasul}

Pasul is a fishing method wherein the fisherman uses a stick usually bamboo tied with a nylon with a hook on its tip for the bait. Bait used are small fishes or worms.

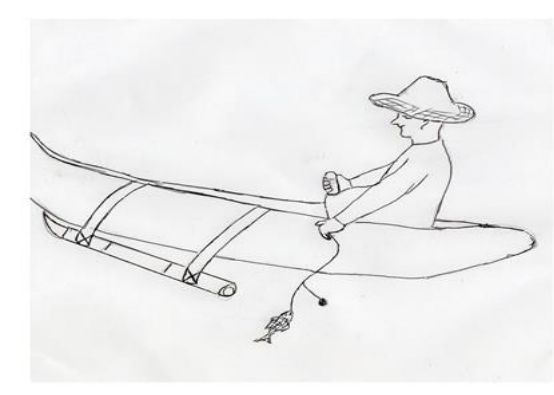

Figure 5. Pasul

\subsubsection{Bubo}

Bubo is made up of bamboo sticks formed as a cage for trapping fish. It is rectangular in shape with an opening at one side of it. Inside the bubo is baited with small fish or feeds to attract bigger fish and even squids. Once the fish or squid enters the opening, it feeds on the bait, becomes bigger and is trap.

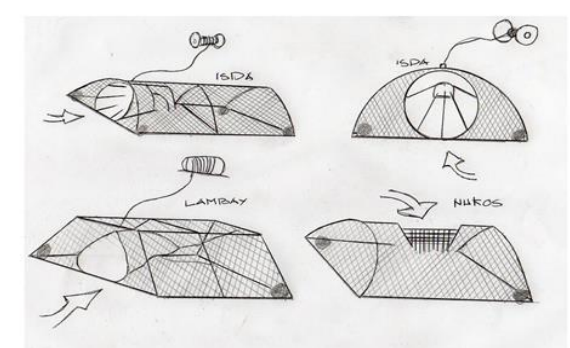

Figure 6. Bubo 


\subsubsection{Patuloy sa Adlaw}

This fishing method uses a nylon net colored white to catch fish. Usually two people do the fishing in patuloy fishing method. The holes of the net is number six (6). The fishermen throw the net and when there are fishes, they pull back the nets with bare hands.

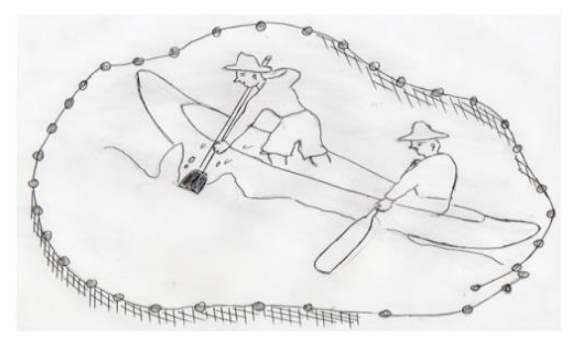

Figure 7. Patuloy sa Adlaw

\subsubsection{Patuloy sa Gabii}

This fishing method is similar with patuloy sa adlaw method. The only difference between them is that in this method, the nylon net use is number eight (8). The net holes is smaller compared to the net in patuloy sa adlaw.

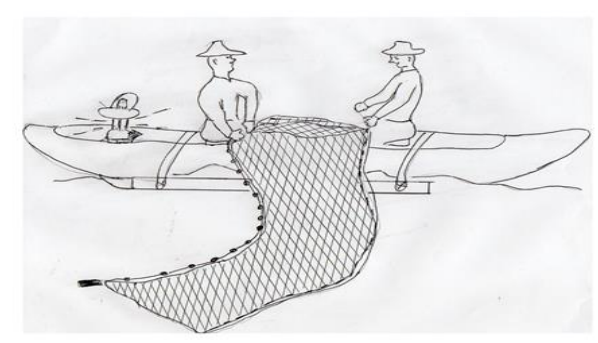

Figure 8. Patuloy sa Gabii

\subsubsection{Pahulbot sa Mabaw}

Pahulbot sa mabaw is a fishing method which employs two (2) fishermen to catch fish. The net use is much stronger than the net use in patuloy. Usually the nets are colored green and is binded with large stones to enable the nets to touch the sea floor. This is done in shallower portion of the sea, hence the word "mabaw" which means shallow. This kind of fishing method is illegal and is not encouraged because it destroys the corals which are the habitat of the fish. When the fishermen pulls the net, it drags the corals and destroys it.

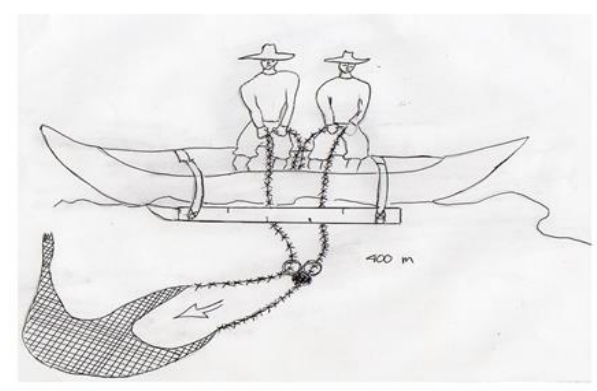

Figure 9. Pahulbot sa Mabaw 


\subsubsection{Pahulbot sa Lalum}

From the Bisaya word "lalum" which means deep, the pahulbot sa lalum operates in deeper sea waters in Pamintayan. It is the same fishing strategy with pahulbot sa mabaw and the only differences are that it employs five (5) fishermen and instead of pulling the nets with bare hand, it uses a rotator made of wood operated by two (2) men to bring on the net. It is illegal and discouraged because it destroys the coral reefs, but according to my key informant there are still fishermen who practice this fishing method.

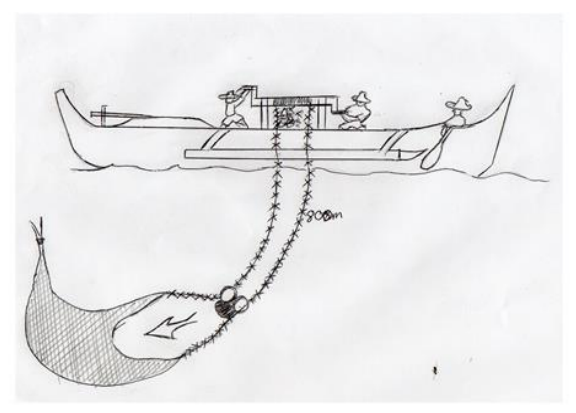

Figure 10. Pahulbot sa Lalum

\subsubsection{Palutaw sa Kawayan}

This fishing structure is spherical in shape and is made up of bamboo posts in each corner, a fishnet, a bamboo pole which serve as pathway around the fish structure. A fishnet tied on the four corner, permanently immersed in the seawater is put up inside the structure. The fishnet must be very low enough that during low tide the net is still partially submerged in the seawater. The fishes are nurtured inside the fishnet until it is ready to harvest. The tides affects the extent of submergence of the fishnet by the seawater.

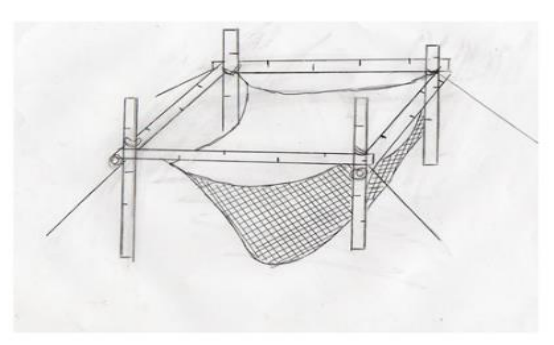

Figure 11. Palutaw sa Kawayan

\subsubsection{Palutaw sa Baril}

This fish structure is rectangular in shape. It uses many sealed painted barrels to make the structure float. The barrels are painted to prevent rusting. The fish nets cannot be seen in the surface rather it is submerge in the seawater. The submerged fishnet formed a rectangular shape. Fish species commonly raised in this fish structure is "lapu-lapu". This type of fishing structure is adaptive to seawater level rise. A cement slabs or big stones are put down beneath the structure in the sea floor and is connected to the bamboo poles. The bamboo poles served as a pathway feeding the fish. The cement slabs or big stones stabilize the fish structure. It holds the fish structure in place and prevents it from drifting away. 


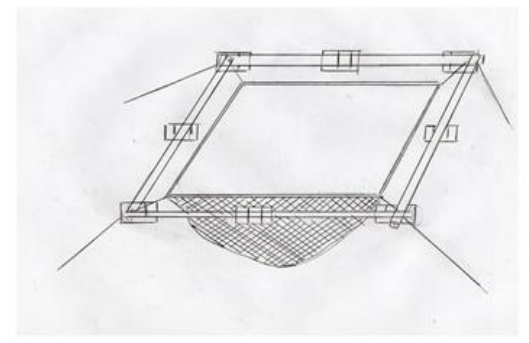

Figure 12. Palutaw sa Baril

\subsubsection{Pamana}

It can be done in the morning or evening. When doing pamana in the evening, you will use flashlight that is waterproof and put it in the head using rubber. The framework of this gear is like an armalight gun that could be a home-made wood. Its arrow is a long, stainless steel. The arrow is secured tight in the body of the wood by a nylon so that when fish are being pinned by the arrow, it cannot escaped far. It is being dragged by the fishermen when fish are being pinned. This kind of fishing could be done in shallow waters or in deep waters. The divers will dive mostly in coral reefs and secure a rope on his leg connected to his boat so that the boat will not be dragged by the sea current and wave.

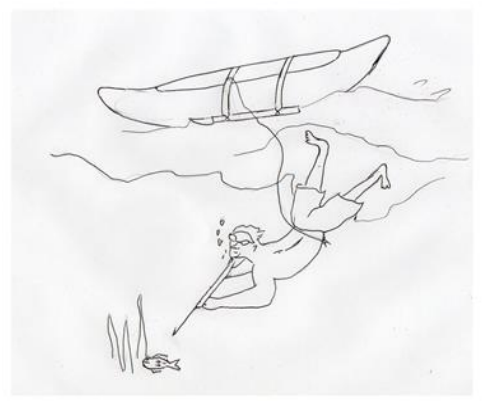

Figure 13. Pamana

\subsubsection{Tapsay}

This type of fishing practice employs two fishermen to perform. They will drag the long rope from the other side of the sea going to the stationed posts where the fishes are being trap and caught. The dragging should be fast. The rope drag by the fishermen is fully hanged with coconut husks from side to side. The coconut husks will scare the fishes and moves them unto the trap. The trap is a net with an eye of 7 centimeters. Above the net is called "pataw" which will make the net float. It is posted toward the intertidal zone of the sea. This fishing practice is done in shallow water during low tide. Most of the fish caught in this type of fishing in the area is called "gisaw".

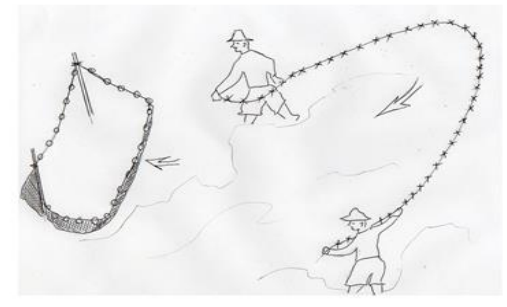

Figure 14. Tapsay 


\subsubsection{Panguyap}

This fishing practice employs two person to perform the activity. Most of the fishes caught in this type of fishing are small fishes like bolinao, uyap, crabs and other small fishes. This could be performed in shallow waters and could also be performed in deeper waters by the use of boats. This fishing practice is done during daytime either in the morning, noon or afternoon. The first part of this gear is called the mouth which is a very fine mesh size net. Often mosquito nets are being transformed to be used in this gear. Two bamboo poles are used on the sides of this gear for better handling and mobilization. The mouth of this gear is being lowered down in the sea water and allow or catch fishes and other marine animals in its mouth and being transported to its belly part which is also a very fine net with a very small mesh size. This kind of fishing is done anytime of the day.

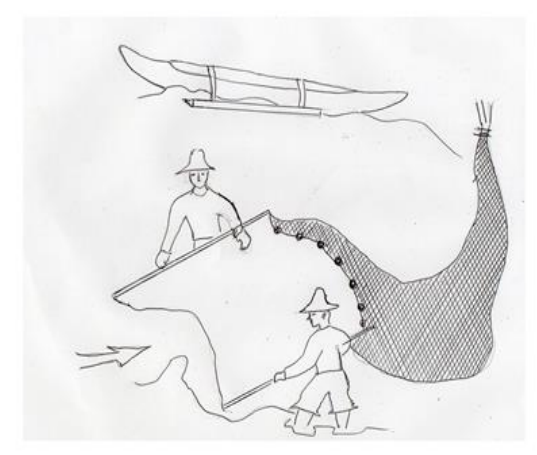

Figure 15. Panguyap

\subsubsection{Palangri}

This fishing practice could be done by one person. It employs a long strand of nylon with hooks with it. About two hundred hooks can be made being incorporated in the long strand of nylon. The fisherman can add more hooks as desired. The long strand of nylon is properly placed in a square frame and attached its hook on the edge of the frame forming a round shape. To catch fish, the tip of the nylon is being released to the seawater and slowly get the hook of the nylon from the edge of the square frame, little by little. The hook is baited with small fishes or worms. This kind of fishing is practiced in the area about 4:00 am. The hooks are released about 4:30 am and the fishing is done around 7:00 am.

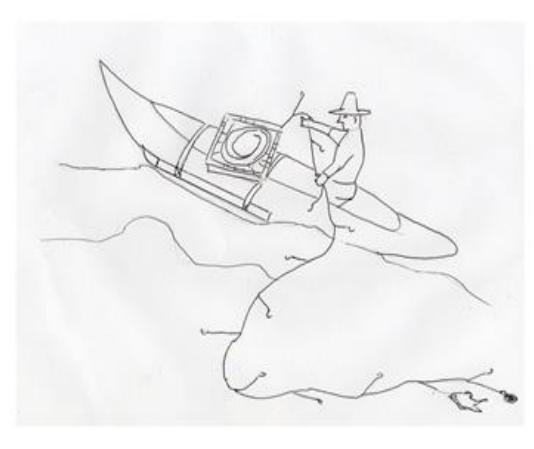

Figure 16. Palangri

\subsubsection{Sud-sud}

This type of fishing could be done during daytime or nighttime. Sud-sud fishing could be in the mangroves, coral areas, sea grass areas and deeper portion of the sea. It employs one person to do this kind of fishing. Women in the area do this kind of fishing. Fine mesh size nets are used to capture small fishes, uyap, bolinao, and other 
small fishes. The nets are edge with two bamboo splits on each side. The two bamboo splits are crossed together near its tips. The fishers handle this gear on the two bamboo splits. The bamboo splits are movable to loosen or tighten the net. The fisher have a basket on its back to place the catch fishes on it.

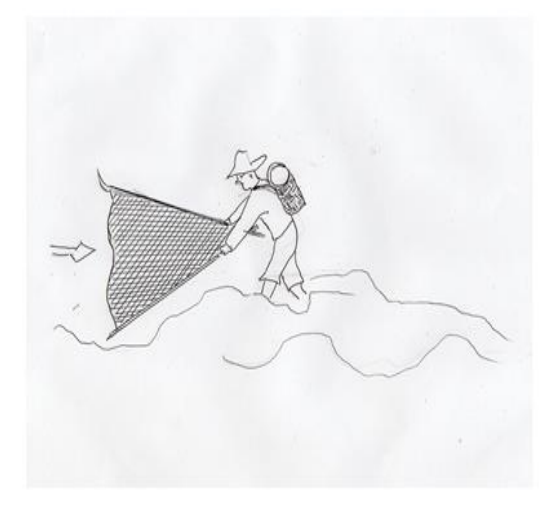

Figure 17. Sud-sud

\subsubsection{Pahubas}

This fishing practice uses long fine nets with bamboo poles as supporters. The bamboo poles with nets are being erected horizontally in the shores. Above the nets are rounded Styrofoam called as "palutaw" to cause the nets to float. Below the nets are rod steels to anchor the net in the seabed. During high tide, this fishing gears are being laid down in the shallower portion of the sea near the shore. During low tide, as the seawater subsided, the fishes which goes with the seawater are trapped in the nets. When the collection of fishes have been done, the fishing gears are being pulled out and are being set up once high tide will come.

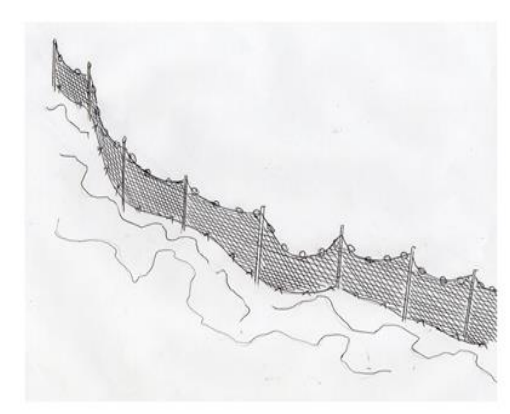

Figure 18. Pahubas

\subsubsection{Tawer-tawer or Balitbit}

This fishing practice is a small version of bunsod fishing. About Php 15,000.00 is the cost of constructing tawer-tawer or balitbit. Nets used in this kind of fishing is the same with bunsod. The fishing technique is $\mathrm{V}$-shaped with a pocket of net in the center. Once fishes enter in the pocket portion, it is being lifted up for fish gathering. The V-shaped part of this kind of fishing should face the sea water current or water current from the river. 


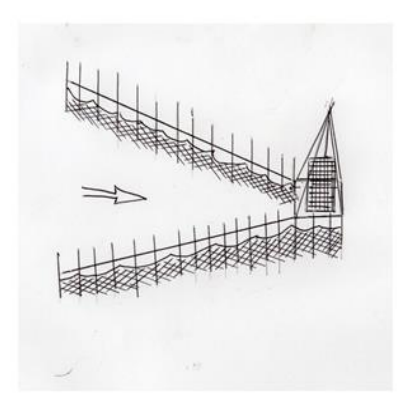

Figure 19. Tawer-tawer or Balitbit

\subsubsection{Panubli}

The fishers use "tubli" a local plant known for its poisonous substance. The "tubli" plant is pounded by stone to release its substance and put it in areas having a school of fish. The exposed fishes are poisoned by the tubli and are catched by the fishers. Tubli fishing is done during daytime by one or two fishers.

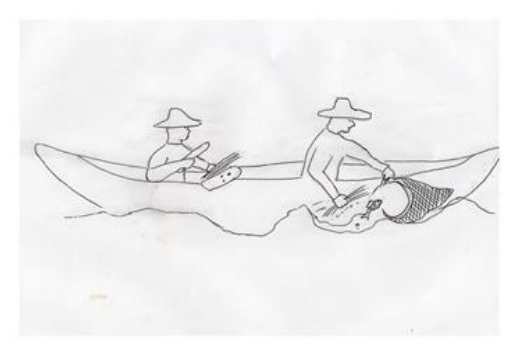

Figure 20. Panubli

\subsubsection{Panguryente}

Panguryente fishing uses a rod steel with current to stun the fish. This fishing activity is done during daytime by one or two fishers. The fish is electrified and paralyzed when exposed to panguryente fishing.

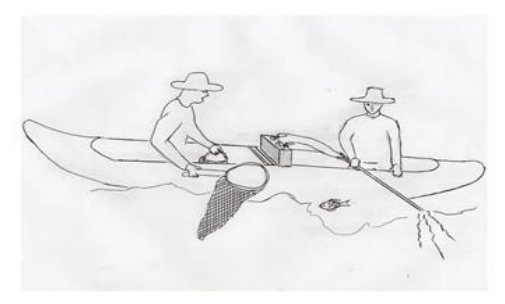

Figure 21. Panguryente

\subsubsection{Trol}

This kind of fishing employs a motorboat and two fishers. The net is being dragged while the motorboat is running. Connected over the net are two flat square like plated steel which weighted the net. Its movement in the seabed scarce the fish, destroys coral reef and seagrasses, and disturb the sediments. This type of fishing is illegal because it destroys and disturb marine ecosystem like coral reef, seagrasses and the sea bottom. 


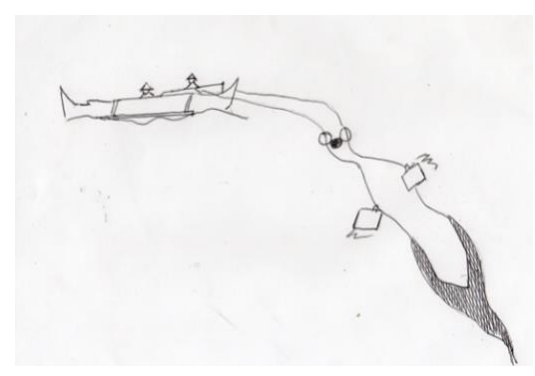

Figure 22. Trol

\subsubsection{Laya}

This fishing technique uses a net to catch fish. Catching fish with this fishing technique could be in the deeper portion of the sea which uses a boat or in a shallower portion near the seashore. The net had small round shape thing called palutaw. Palutaw are any material which floats that includes rubbers or Styrofoam. Laya fishing is mostly done during daytime.

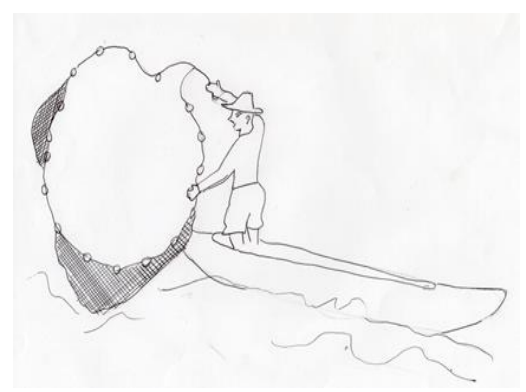

Figure 23. Laya

\subsubsection{Ulang-ulang}

Ulang-ulang is a fishing technique intended to catch squid. A nylon is baited with a fake shrimp. The fake shrimp is made of wood coated with a gray color so as to look like a real shrimp. The tail portion of the shrimp composed of ten limbs arranged by five (5) forming upper and lower portion are tiny curved steel. The tiny curved steel when eaten by the squid will pierced in the mouth of the squid and locked its mouth in the steel causing it to be catch.

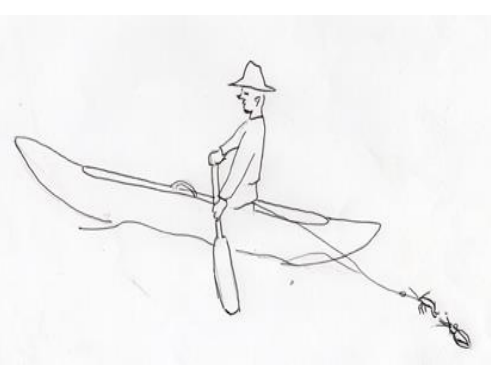

Figure 24. Ulang-ulang

\section{Conclusion}

A total of 23 fishing crafts and gears were identified in Dumanquillas Bay. Of the twenty-three fishing crafts and gears, five among it are considered illegal base on R.A. 10654 otherwise known as the Philippine Fisheries Code. The five (5) considered illegal fishing practices includes "panguryente" (Sec. 92), "panubli" (Sec. 92), "pahulbot 
sa mabaw" (Sec. 97), "pahulbot sa lalum" (Sec. 97), and "trol fishing" (Sec. 97). Dynamite and Muro-Ami fishing were not found and practiced in the area.

The illegal fishing practices in the bay should be stop to prevent damage on the seagrass beds, coral reefs, bottom of the sea, and eggs of fishes. These marine ecosystems should be keep healthy as these are critical for life support system. Information and education campaign, alternative livelihood, and strong implementation of the fishery law are encouraged to be promoted by the local authorities in partnership with concerned stakeholders for the sustainability of Dumanquillas Bay.

\section{Acknowledgements}

The authors convey their utmost sincerest gratitude and appreciation to Pamintayan Brgy Captain Dimasagka for the approval to conduct the study and for the security; to the fisherfolks of Pamintayan for the full cooperation and generous hospitality; to Ate Neneng and family for the unwavering support; Ruflo family for the accommodation and help; Jetro Rivera, Albert Pagayon, and Jungie Diodos for the assistance, accompaniment and laughers.

\section{References}

Bitantos, B. L., Torino, F. G., \& Tampus, A. D. (2020). Marine Resources and Utilization in Buug, Dumanquillas Bay, Philippines. International Network for Natural Sciences Quality Sciences Publishing. https://doi.org/10.12692/ijb/17.3.124-133

Boyd Pfeiffer, C. (1999). Fly Fishing Saltwater Basics: Saltwater Basics. Stackpole Books.

Brandt, V., Gabriel, O., Lange K., Dahm, E., \& Wendt, T. (2005). Von Brandt's Fish Catching Methods of the World. John Wiley \& Sons, Inc.

Coastal Communities - GOV.PH. (n.d.). Retrieved February 4, 2021, from https://www.gov.ph/web/green-climate-fund/coastal-communities

Cristie, P., Armada, N. B., White, A. T., Gulayan, A. M., \& de Dios, H. H. Y. (2006). Coastal environmental and fisheries profile of Danajon Bank, Bohol, Philippines. Fisheries Improved for Sustainable Harvest (FISH) Project, Cebu City, Philippines. ResearchGate. Retrieved from https://www.researchgate.net/publication/238080858_Coastal_environmental_and_fisheries_profile_of_Da najon_Bank_Bohol_Philippines

Dale, G. R. (2006). The Nature of Paleolithic Art, (p. 298). University of Chicago Press.

Fishing \& Farming methods. (n.d.). Monterey Bay Aquarium Seafood Watch. Retrieved February 4, 2021, from https://www.seafoodwatch.org/seafood-basics/fishing-and-farming-methods/

Food and Agriculture Organization of the United Nations. (1971). Modern Fishing Gear of the World, 3: Fish Finding, Purse Seining, Aimed Trawling. Fishing News Books.

National Geographic. (2021). Know before you go: the Philippines. Retrieved February 1, 2020 from https://www.nationalgeographic.com/travel/destinations/asia/philippines/partner-content-know-before-yougo-the-philippines/

Ng, P. K. L., Mendoza, J. C. E., \& Manuel-Santos, M. R. (2009). Tangle Net Fishing: An Indigenous Method Used in Balicasag Island, Central Philippines. The Raffles Bulliten of Zoology.

Pauly, D. (1998). Fishing Down Marine Food Webs. Science, 279(5352), 860-863. https://doi.org/10.1126/science.279.5352.860

Pomeroy, R. S., Ratner, B. D., Hall, S. J., Pimoljind, J., \& Vivekanandan, V. (2006). Coping with disaster: Rehabilitating coastal livelihoods and communities Coastal Habitats and Resources Management Project. Marine Policy. Elsevier. https://doi.org//10.1016/j.marpol.2006.02.003

Prado, J., \& Dremière P. Y. (1990). Fisherman's Workbook. Fishing News Books Oxford.

Recent Trends in Monitoring, Control and Surveillance Systems For Capture Fisheries (FAO Fisheries Technical Papers) by Food and Agriculture Organization of the United Nations (2003-02-28). (1772). FAO.

Sampang, A. G. (2007). The Calamian Tagbanwa Ancestral Domain (Coron Island, Palawan, Philippines): Evaluation of traditional fishing practices towards biodiversity conservation and sustainability. World Fish.

Schultz, K. (1999). Fishing Encyclopedia: Worldwide Angling Guide. John Wiley \& Sons.

Waldman, J. (2005). 100 Weird Ways to Catch Fish. Stackpole Books. 
White, A. T., \& Cruz-Trinidad, A. (1998). The Values of Philippine Coastal Resources: Why Protection and Management are Critical. Coastal resource Management Project.

\section{Copyrights}

Copyright for this article is retained by the author(s), with first publication rights granted to the journal.

This is an open-access article distributed under the terms and conditions of the Creative Commons Attribution license (http://creativecommons.org/licenses/by/4.0/). 